\title{
Extracts of Azadirachta indica and Melia azedarach seeds inhibit folliculogenesis in albino rats
}

J.K. Roop, P.K. Dhaliwal and S.S. Guraya
Department of Zoology and Fisheries, Punjab Agricultural University, Ludhiana, Punjab, India

Correspondence
J.K. Roop
Roop-Cottage
204-L, Model Town
Hoshiarpur-146001
Punjab
India
E-mail: jkroop@rediffmail.com
... . . . . . . . . . . . . . . . . . .

Received May 7, 2003

Accepted February 24, 2005

$\ldots \ldots \ldots \ldots \ldots \ldots \ldots$

\begin{abstract}
The seed oil of Azadirachta indica A. Juss (neem) is used in traditional medicine for its antidiabetic, spermicidal, antifertility, antibacterial, and wound healing properties. The present study was undertaken to investigate the quantitative aspects of follicular development in cyclic female albino rats ( $135 \pm 10 \mathrm{~g} ; 8$ groups with 6 animals in each group) after oral administration of polar (PF) and non-polar (NPF) fractions

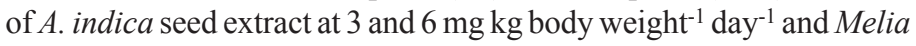

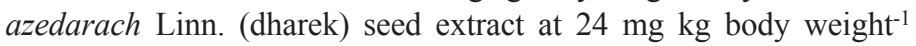
day $^{-1}$ for 18 days. The extracts were prepared using a flash evaporator at $35^{\circ} \mathrm{C}$ and then dissolved in olive oil to prepare doses on a per $\mathrm{kg}$ body weight basis. There was a significant reduction $(\mathrm{P}=0.05)$ in the number of normal single layered follicles (A. indica: $0.67 \pm 0.33$ and $4.67 \pm 2.03$ after 3 and $6 \mathrm{mg} / \mathrm{kg} \mathrm{NPF}$, and $3.33 \pm 1.67$ and $1.00 \pm 1.00$ after 3 and $6 \mathrm{mg} / \mathrm{kg}$ PF vs control: $72.67 \pm 9.14$ and M. azedarach: 0.60 \pm 0.40 and $1.80 \pm 1.2$ after $24 \mathrm{mg} / \mathrm{kg}$ PF and NPF, respectively, $v s$ control: $73.40 \pm 7.02$ ) and follicles in various stages (I-VII) of follicular development in all treatment groups. These extracts also significantly reduced $(\mathrm{P}=0.05)$ the total number of normal follicles in the neem (14.67 \pm 5.93 and $1.00 \pm 1.00$ after 3 and $6 \mathrm{mg} / \mathrm{kg} P F$ and 3.67 \pm 0.88 and $5.33 \pm 2.03$ after 3 and $6 \mathrm{mg} / \mathrm{kg} \mathrm{NPF})$ and dharek (13.00 \pm 3.58 and $14.60 \pm 2.25$ after $24 \mathrm{mg} / \mathrm{kg} \mathrm{NPF}$ and PF) treatments compared to control $(216.00 \pm 15.72$ and $222.20 \pm 19.52$, respectively). Currently, indiscriminate use of persistent and toxic rodenticides to control rodent populations has created serious problems such as resistance and environmental contamination. Therefore, it becomes necessary to use ecologically safe and biologically active botanical substances that are metabolized and are not passed on to the next trophic level, and that interfere with the reproductive potential particularly growth and differentiation of follicles. This may help elevate the socio-economic status of the country. Thus, the present study is an attempt to investigate the effects of $A$. indica and $M$. azedarach seed extracts on reproduction of albino rats.
\end{abstract}

Key words

- Folliculogenesis

- Azadirachta

- Melia

- Plant products

- Antifertility
Rodents pose a great threat to the economy of India by inflicting $5-10 \%$ damage to the agricultural produce every year (1). The rodent problem is due to their high rate of reproduction, complex behavior and ability to adapt to diverse ecological conditions. The indiscriminate use of persistent and toxic rodenticides has created serious problems like resistance and environmental contamination. It has, therefore, become necessary to 
use biologically active botanical substances or fertility-regulating agents of plant origin which are ecofriendly in approach and interfere with the natural patterns of reproduction (2), particularly growth and differentiation of follicles. Successful growth and differentiation of the ovarian follicle is known to be under the control of the follicle-stimulating hormone (FSH) and luteinizing hormone (LH) produced by the pituitary. Many recent in vitro and in vivo studies have shown that the process of folliculogenesis is mediated by cAMP and is modulated by many local paracrine and autocrine factors in addition to the gonadotrophins themselves $(3,4)$. These modulatory factors include steroid hormones and non-steroidal factors such as growth factors. Although gonadotrophins are required for folliculogenesis, factors that regulate the cyclic appearance and atresia of dominant follicles and other follicles of variable size are of great significance. Various factors causing and regulating follicular atresia may include age, stage of the reproductive cycle, pregnancy, lactation, hormones of extraovarian or intraovarian sources, a genetic 'program', nutrition including minerals, ischemia, seasons, and plant extracts (3-5). Extracts of many plants are also known to possess abortifacient activity in female gerbils, rats, mice, and rabbits $(2,6-8)$. The contraceptive effect of neem seed oil and leaf extract has been demonstrated in male and female rats $(9,10)$. Though the quantitative aspects of follicular development in rats receiving Azadirachta seed oil have been reported (5), the effect of polar (PF) and nonpolar (NPF) fractions of Azadirachta indica extract on follicular kinetics remains to be investigated. In the case of Melia azedarach, even the preliminary information regarding the effects of its extracts on female reproduction is not available. Thus, the present investigation was undertaken to study the quantitative aspects of folliculogenesis in female albino rats after oral administration of PFs and NPFs of $A$. indica and $M$. azedarach seed extracts.

The seeds of shade-dried matured drupes of A. indica (100 g) and M. azedarach (100 g) were powdered and the fractions were separately extracted with methanol (for PF) and hexane (for NPF). The filtrates were then evaporated in a flash evaporator at $35^{\circ} \mathrm{C}$, after which a dark slurry (fractions) was obtained. These fractions were then dissolved in olive oil (vehicle) to prepare doses on a per kg body weight basis.

Mature female albino rats $(135 \pm 10 \mathrm{~g})$ bred in the Small Animal Colony of the Punjab Agricultural University, Ludhiana, were used for the present investigation. The animals had free access to standard diet and water. The stage of the estrous cycle of each animal was determined by observing vaginal smears (using saline, $0.9 \% \mathrm{NaCl}, \mathrm{w} / \mathrm{v}$ ) daily between 9:00 and 10:00 am. Rats showing at least three regular 4-day cycles and that are also in the diestrous stage of the cycle received orally PF and NPF of seed extract of

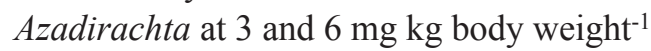
day $^{-1}$ and of seed extracts of Melia at $24 \mathrm{mg}$ $\mathrm{kg}$ body weight ${ }^{-1}$ day $^{-1}$ for 18 days. Animals were divided into 8 groups of 6 each. Olive oil was given to rats in the control group. On the 19th day, all rats were sacrificed. The ovaries were dissected out, cleaned of fat and fixed in Bouin's fluid. They were dehydrated in graded alcohols, cleared in benzene, embedded in paraffin and then serially sectioned at $7 \mu \mathrm{m}$ and stained with hematoxylin and eosin. All the sections from each ovary were used to quantify the number of normal follicles. The follicles were classified into seven stages according to the number of granulosa cell (GC) layers around the oocyte (11). Stage I: preantral follicles with two to three GC layers surrounding the oocyte; stage II: preantral follicles with four to five GC layers; stage III: preantral follicles with six to seven GC layers; stage IV: preantral follicles with eight or more complete GC layers; stage V: follicles with early signs of antrum formation, i.e., with small 
clear lacunae appearing among the GC; stage VI: follicles with a single medium-sized antral cavity or with two small cavities on either side of the oocyte; stage VII: graafian follicles with a large, well-formed antral cavity. Besides these, single-layered follicles (preantral follicles with a single complete GC layer surrounding the oocyte) were also counted. The number of follicles recorded in all stages of follicular development represented the absolute number of normal follicles per ovary. Thus, the total number of normal follicles in seven stages along with single-layered follicles were counted in the ovaries of control and treated rats. Data were analyzed by standard procedures in a completely randomized block design. A probability of $\mathrm{P}=0.05$ was considered significant for all comparisons.

There was a significant reduction in the number of normal single-layered follicles in rats receiving 3 and $6 \mathrm{mg} / \mathrm{kg} \mathrm{PF}$ and NPF (3.33-1.00 and 0.67-4.67, respectively) of Azadirachta (Table 1) and $24 \mathrm{mg} / \mathrm{kg}$ PF and
NPF (0.60-1.80) of Melia (Table 2) seed extracts compared to their respective control groups (72.67 and 73.40). There were no statistical differences among the seed extract treatments. Similarly, a significant reduction was observed in the number of normal follicles in stages I, II, III, and IV after treatment with Azadirachta fractions and in stages I-VII after treatment with Melia fractions compared to control. There were no statistical differences among treatments. The number of follicles in stages V-VII in the ovaries of rats treated with Azadirachta seed fractions was significantly reduced except at 3 $\mathrm{mg}$ PF, when the number of stage VII (4.00) follicles was similar to control (5.33; Table 1). Follicles in stages II, III and V were absent in the groups treated with 6 and $3 \mathrm{mg}$ NPF of Azadirachta extract. At $6 \mathrm{mg}$ PF, not even a single normal follicle belonging to stages I-VII was observed. The result showed a significant reduction in the total number of normal follicles in all treated groups compared to control, the reduction being maxi-

Table 1. Number of normal follicles in various stages of follicular development in the ovaries of albino rats treated orally with polar fraction and non-polar fraction of Azadirachta indica (neem) seed extract.

\begin{tabular}{|c|c|c|c|c|c|c|c|c|c|}
\hline \multirow[t]{2}{*}{ Dose } & \multicolumn{8}{|c|}{ Number of follicles in various stages of development } & \multirow{2}{*}{$\begin{array}{c}\text { Total number } \\
\text { of follicles }\end{array}$} \\
\hline & Single layered & I & II & III & IV & V & $\mathrm{VI}$ & VII & \\
\hline Control & $\begin{array}{c}72.67 \pm 9.14^{a} \\
(8.55)\end{array}$ & $\begin{array}{c}43.67 \pm 4.81^{a} \\
(6.67)\end{array}$ & $\begin{array}{c}34.33 \pm 2.60^{\mathrm{a}} \\
(5.94)\end{array}$ & $\begin{array}{c}28.00 \pm 4.93^{a} \\
(5.35)\end{array}$ & $\begin{array}{c}14.00 \pm 1.53^{a} \\
(3.86)\end{array}$ & $\begin{array}{c}8.67 \pm 2.19^{a} \\
(3.07)\end{array}$ & $\begin{array}{c}9.33 \pm 2.60^{a} \\
(3.16)\end{array}$ & $\begin{array}{c}5.33 \pm 1.76^{\mathrm{a}} \\
(2.46)\end{array}$ & $\begin{array}{c}216.00 \pm 15.72^{a} \\
(14.71)\end{array}$ \\
\hline \multicolumn{10}{|c|}{ Polar fraction } \\
\hline $3 \mathrm{mg} / \mathrm{kg}$ & $\begin{array}{c}3.33 \pm 1.67^{b} \\
(1.97)\end{array}$ & $\begin{array}{c}1.00 \pm 1.00^{b} \\
(1.33)\end{array}$ & $\begin{array}{l}0.67 \pm 0.66^{b} \\
(1.24)\end{array}$ & $\begin{array}{l}0.33 \pm 0.33^{b} \\
(1.14)\end{array}$ & $\begin{array}{l}1.00 \pm 1.00^{b} \\
(1.33)\end{array}$ & $\begin{array}{c}1.33 \pm 0.33^{b} \\
(1.52)\end{array}$ & $\begin{array}{l}3.00 \pm 3.00^{b} \\
(1.72)\end{array}$ & $\begin{array}{c}4.00 \pm 0.58^{a} \\
(2.23)\end{array}$ & $\begin{array}{c}14.67 \pm 5.93^{b} \\
(3.82)\end{array}$ \\
\hline $6 \mathrm{mg} / \mathrm{kg}$ & $\begin{array}{c}1.00 \pm 1.00^{b} \\
(1.33)\end{array}$ & $\begin{array}{l}0.00^{b} \\
(1.00)\end{array}$ & $\begin{array}{l}0.00^{b} \\
(1.00)\end{array}$ & $\begin{array}{l}0.00^{b} \\
(1.00)\end{array}$ & $\begin{array}{l}0.00^{b} \\
(1.00)\end{array}$ & $\begin{array}{l}0.00^{c} \\
(1.00)\end{array}$ & $\begin{array}{l}0.00^{b} \\
(1.00)\end{array}$ & $\begin{array}{l}0.00^{b} \\
(1.00)\end{array}$ & $\begin{array}{l}1.00 \pm 1.00^{c} \\
(1.33)\end{array}$ \\
\hline \multicolumn{10}{|c|}{ Non-polar fraction } \\
\hline $3 \mathrm{mg} / \mathrm{kg}$ & $\begin{array}{c}0.67 \pm 0.33^{b} \\
(1.28)\end{array}$ & $\begin{array}{l}0.00^{\mathrm{b}} \\
(1.00)\end{array}$ & $\begin{array}{l}0.00^{b} \\
(1.00)\end{array}$ & $\begin{array}{l}0.00^{\mathrm{b}} \\
(1.00)\end{array}$ & $\begin{array}{c}0.33 \pm 0.33^{b} \\
(1.14)\end{array}$ & $\begin{array}{l}0.00^{c} \\
(1.00)\end{array}$ & $\begin{array}{c}1.33 \pm 0.88^{b} \\
(1.47)\end{array}$ & $\begin{array}{c}1.33 \pm 0.88^{b} \\
(1.47)\end{array}$ & $\begin{array}{c}3.67 \pm 0.88^{c} \\
(2.14)\end{array}$ \\
\hline $6 \mathrm{mg} / \mathrm{kg}$ & $\begin{array}{l}4.67 \pm 2.03^{b} \\
(2.29)\end{array}$ & $\begin{array}{l}0.33 \pm 0.33^{b} \\
(1.14)\end{array}$ & $\begin{array}{l}0.00^{b} \\
(1.00)\end{array}$ & $\begin{array}{l}0.00^{b} \\
(1.00)\end{array}$ & $\begin{array}{l}0.00^{b} \\
(1.00)\end{array}$ & $\begin{array}{l}0.00^{c} \\
(1.00)\end{array}$ & $\begin{array}{l}0.33 \pm 0.33^{b} \\
(1.14)\end{array}$ & $\begin{array}{l}0.00^{b} \\
(1.00)\end{array}$ & $\begin{array}{l}5.33 \pm 2.03^{b c} \\
(2.45)\end{array}$ \\
\hline$C D$ & (1.30) & $(0.71)$ & $(0.46)$ & (0.67) & (0.58) & (0.50) & $(1.25)$ & $(0.70)$ & (1.53) \\
\hline
\end{tabular}


mum at $3 \mathrm{mg}$ NPF (3.67) and $6 \mathrm{mg}$ PF (1.00) of Azadirachta seed extract. Also, the number of normal follicles was significantly decreased in the ovaries of rats treated with 24 $\mathrm{mg}$ PF and NPF of Melia seed extract.

The significant reduction in the number of normal follicles in all treatment groups compared to control may have been due to disruption of the process of follicle selection due to atresia (12). Follicular growth is regulated by endocrine (FSH, LH and prolactin) and local (paracrine and autocrine) factors. The latter include steroid hormones (e.g., progestins, estrogens and androgens) produced by different cell types of the ovary and various non-steroidal regulators (e.g., oocyte maturation inhibitor, luteinization stimulator, luteinization inhibitor, FSH inhibitor, insulin-like growth factors, transforming growth factors, epidermal growth factor, platelet-derived growth factor, inhibin, and activin) $(3,12-14)$. Many of the changes occurring during oocyte growth and maturation also appear to be mediated or influenced by ions, hormones (especially gonadotrophins and steroids) and endogenous cytoplasmic factors such as maturation promoting factor and growth factors $(4,12,15)$. On this basis, we may assume that these agents might be interfering at the level of receptors and mRNA expression of these factors. Thus, there is inhibition of follicular growth which is gonadotrophin dependent and the recruited follicles are unable to develop further in the ovaries of treated rats compared to control. Also, the total number of normal follicles was significantly reduced in rats orally treated with $4.6 \mathrm{ml} / \mathrm{kg}$ Azadirachta seed oil for 18 days (5) and with 2 and $4 \mathrm{mg} / \mathrm{kg}$ nicotine intraperitoneally (16).

Similarly, many plant extracts have been reported to affect folliculogenesis in rodents: the primordial follicle has been reduced in the ovaries of female gerbils treated with Cannabis extract at $2.5 \mathrm{mg} /$ day for 60 days (17) and completely lost in rats treated with an aqueous suspension of the dried seed powder of Sapindus trifoliatus at 50, 100 and $150 \mathrm{mg} / \mathrm{kg}$ for 31 days (18) and in guinea pigs treated with the hexane extract of Ferula jaeschkeana (19). Also, a decrease in the number of graafian follicles has been reported to occur in albino mice orally treated with nicotine at $0.3 \mathrm{mg} / \mathrm{kg}$ for 15 days (20). Thus, we may conclude that the PF and NPF of $A$. indica and $M$. azedarach seed extracts

Table 2. Number of normal follicles in various stages of follicular development in the ovaries of albino rats treated orally with polar fraction and non-polar fraction of Melia azedarach (dharek) seed extract.

\begin{tabular}{|c|c|c|c|c|c|c|c|c|c|}
\hline \multirow[t]{2}{*}{ Dose } & \multicolumn{8}{|c|}{ Number of follicles in various stages of development } & \multirow{2}{*}{$\begin{array}{c}\text { Total number } \\
\text { of follicles }\end{array}$} \\
\hline & Single layered & I & II & III & IV & V & $\mathrm{VI}$ & VII & \\
\hline Control & $\begin{array}{c}73.40 \pm 7.02^{a} \\
(8.59)\end{array}$ & $\begin{array}{c}45.00 \pm 3.35^{a} \\
(6.77)\end{array}$ & $\begin{array}{c}35.20 \pm 1.72^{a} \\
(6.01)\end{array}$ & $\begin{array}{c}29.60 \pm 3.28^{a} \\
(5.50)\end{array}$ & $\begin{array}{c}13.80 \pm 1.16^{\mathrm{a}} \\
(3.84)\end{array}$ & $\begin{array}{c}9.00 \pm 1.64^{a} \\
(3.12)\end{array}$ & $\begin{array}{c}10.20 \pm 1.72^{\mathrm{a}} \\
(3.30)\end{array}$ & $\begin{array}{c}6.00 \pm 1.10^{\mathrm{a}} \\
(2.61)\end{array}$ & $\begin{array}{c}222.20 \pm 19.52^{a} \\
(14.93)\end{array}$ \\
\hline \multicolumn{10}{|c|}{ Polar fraction } \\
\hline $24 \mathrm{mg} / \mathrm{kg}$ & $\frac{0.60 \pm 0.40^{b}}{(1.23)}$ & $\begin{array}{c}1.80 \pm 0.37^{b} \\
(1.66)\end{array}$ & $\begin{array}{c}0.60 \pm 0.25^{b} \\
(1.25)\end{array}$ & $\begin{array}{c}1.60 \pm 0.51^{b} \\
(1.58)\end{array}$ & $\begin{array}{c}1.40 \pm 0.51^{b} \\
(1.51)\end{array}$ & $\begin{array}{c}2.40 \pm 1.03^{b} \\
(1.76)\end{array}$ & $\begin{array}{c}3.00 \pm 1.05^{b} \\
(1.93)\end{array}$ & $\begin{array}{c}3.20 \pm 0.37^{b} \\
(2.04)\end{array}$ & $\begin{array}{c}14.60 \pm 2.25^{b} \\
(3.91)\end{array}$ \\
\hline \multicolumn{10}{|c|}{ Non-polar fraction } \\
\hline $24 \mathrm{mg} / \mathrm{kg}$ & g $1.80 \pm 1.2^{b}$ & $\begin{array}{l}2.00 \pm 0.95^{b} \\
(1.64)\end{array}$ & $\begin{array}{c}1.40 \pm 0.98^{b} \\
(1.44)\end{array}$ & $\begin{array}{l}0.80 \pm 0.37^{b} \\
(1.31)\end{array}$ & $\begin{array}{c}1.40 \pm 0.87^{b} \\
(1.45)\end{array}$ & $\begin{array}{c}1.00 \pm 0.32^{b} \\
(1.40)\end{array}$ & $\begin{array}{l}3.20 \pm 1.11^{b} \\
(1.98)\end{array}$ & $\begin{array}{c}1.40 \pm 0.51^{b} \\
(1.51)\end{array}$ & $\begin{array}{c}13.00 \pm 3.58^{b} \\
(3.57)\end{array}$ \\
\hline$C D$ & (0.98) & $(0.70)$ & $(0.60)$ & $(0.67)$ & $(0.64)$ & $(0.70)$ & $(0.82)$ & $(0.54)$ & $(1.25)$ \\
\hline
\end{tabular}




\section{significantly reduced the number of normal tract. This is consistent with its use in folk follicles in rats, with maximum reduction medicine as an anti-conceptional agent.} occurring with $6 \mathrm{mg}$ PF of Azadirachta ex-

\section{References}

1. Parshad VR \& Ahmad N (1996). Rodent pest management in agriculture: Problems, strategies and implementation. Journal of Research of Punjab Agricultural University, 33: 266-281.

2. Dixit VP (1992). Plant products/non-steroidal compounds affecting fertility in the Indian desert gerbil, Meriones hurrianae Jerdon. In: Prakash I \& Ghosh PK (Editors), Rodents in Indian Agriculture. Vol. 1. Scientific Publishers, Jodhpur, India, 595-604.

3. Guraya SS (1998). Cellular and Molecular Biology of Gonadal Development and Maturation in Mammals. Fundamentals and Biomedical Implications. Narosa Publishing House, New Delhi, India, and Springer-Verlag, Heidelberg, Berlin, Germany.

4. Guraya SS (2000). Comparative Cellular and Molecular Biology of Ovary in Mammals. Fundamental and Applied Aspects. Oxford \& IBH Publishing Co. Pvt. Ltd., New Delhi, and Calcutta, India.

5. Dhaliwal PK, Roop JK \& Guraya SS (1999). Effect of neem-seed oil on the quantitative aspects of follicular development in cyclic female rats. Indian Journal of Ecology, 26: 162-166.

6. Al-Tahan FJ (1994). Antifertility effect of castor bean on mice. Fitoterapia, 65: 34-37.

7. Nwobodo EO, Nwafia WC, Ezeigbo JC \& Onwughalu J (1996). The post-coital contraceptive activity of Sida linifolia. Fitoterapia, 67: 291-293.

8. Nath D, Sethi N, Srivastava S, Jain AK \& Srivastava R (1997). Teratogenic evaluation of an indigenous antifertility medicinal plant Gossypium herbaecum in rat. Fitoterapia, 68: 137-139.

9. Jacobson M (1995). Antifertility effects and population control agents. In: Schmutterer (Editor), The Neem Tree - Azadirachta indica A. Juss and other Meliaceous plants. Published jointly by: $\mathrm{VCH}$ Verlagsgescll Schaft, Weinheim, Federal Republic of Germany, and VCH Publishers Inc., New York, 526-530.

10. Dhaliwal PK, Roop JK \& Guraya SS (1998). Antifertility activity of neem-seed oil in cyclic female rats. In: Dhaliwal GS, Randhawa NS, Arora A \& Dhawan AK (Editors), Ecological Agriculture and Sustainable Development. Vol. 2. Indian Ecological Society and Centre for Research in Rural and Industrial Development, Chandigarh, India,
340-346.

11. Kaur P \& Guraya SS (1983). Follicular growth and kinetics during the oestrous cycle, pregnancy and post-partum in the Indian mole rat (Bandicota bengalensis). American Journal of Anatomy, 166: 469489.

12. Guraya SS (1997). Ovarian Biology in Buffaloes and Cattle. Indian Council of Agricultural Research, New Delhi, India.

13. Hirshfield AN (1991). Development of follicles in the mammalian ovary. International Review of Cytology, 124: 43-101 (Review).

14. Driancourt MA, Gougeon A, Royere D \& Thibault C (1993). Ovarian function. In: Thibault C \& Levasseur MC (Editors), Reproduction in Mammals and Man. Ellipses, Paris, France, 281-305.

15. Driancourt MA \& Thuel B (1998). Control of oocyte growth and maturation by follicular cells and molecules present in follicular fluid: A review. Reproduction, Nutrition, Development, 38: 345-362.

16. Patil SR, Patil SR, Bhaktaraj B \& Patil SB (1999). Effect of graded doses of nicotine on ovarian and uterine activities in albino rats. Indian Journal of Experimental Biology, 37: 184-186.

17. Dixit VP, Arya M \& Lohiya NK (1976). Mechanism of action of chronically administered Cannabis extract on the female genital tract of gerbils Meriones hurrianae. Indian Journal of Physiology and Pharmacology, 20: 38-41.

18. Singh SP \& Singh K (1994). Effect of Sapindus trifoliatus seed on the fertility of female albino rats. Cell Signalling and Ova Implantation (Abstracts). The International Symposium on Cell Signalling and Ova-Implantation. All India Institute of Medical Science, New Delhi, India, November 21-23.

19. Pathak S, Jonathan S \& Prakash AO (1995). Timely administration of extract of Ferula jaeschkeana causes luteolysis in the ovary of cyclic guinea pig. Indian Journal of Physiology and Pharmacology, 39: 395-399.

20. Patil SR, Ravindra, Patil SR, Londonkar R \& Patil SB (1998). Nicotine induced ovarian and uterine changes in albino mice. Indian Journal of Physiology and Pharmacology, 42: 503-508. 